\title{
ANALISIS LEGAL SOSIAL TERHADAP KONDISI KESETARAAN DAN KEADILAN GENDER DALAM MENDUKUNG PEMBANGUNAN BERKELANJUTAN INDONESIA
}

\author{
Indra Kusumawardhana \\ Department of International Relations \\ Faculty of Communication and Diplomacy \\ Universitas Pertamina \\ Email : Kusumawardhana.up@gmail.com/ \\ indra.kusumawardhana@universitaspertamina.ac.id
}

\begin{abstract}
ABSTRAK
Tak dapat disangkal lagi persoalan gender telah menjadi sebuah isu yang sangat penting secara global. Urgensi ini mengemuka dengan masuknya isu gender sebagai salah satu tujuan utama transformasi langkah kolektif global yakni Sustainable Development Goals (SDGs) pada tahun 2015 lampau yang menjadi sebuah bukti nyata semakin kuatnya kepedulian masyarakat dunia terkait polemik kesetaraan dan keadilan gender (un.org). Namun polemik kesetaraan dan keadilan gender tetap menjadi sebuah tugas yang jauh dari kata usai untuk Indonesia, terutama jika merujuk pada kenyataan bahwa peran perempuan di Indonesia masih menunjukan berbagai ketimpangan dalam korelasinya dengan pembangunan secara holistik. Kondisi tersebut tidak terlepas dari kenyataan bahwa hingga kini Indonesia belum memiliki sebuah undang-undang yang mengakomodasi secara komprehensif tentang perlindungan hak-hak perempuan dari bentuk-bentuk diskriminasi terhadap perempuan, dan pelanggaran hak asasi perempuan dalam pembangunan Indonesia. Dalam konteks tersebut, kajian ini dirajut dalam kerangka urgensi kesetaraan dan keadilan gender dalam pembangunan Indonesia yang menuntut Undang - Undang yang mampu menjadi payung hukum komprehensif bagi implementasi kesetaraan dan keadilan gender. Menggunakan pendekatan sistem sosial, gender, serta berbagai konseptual yang tersedia dalam memahami perempuan dan pembangunan; serta menggunakan metodologi kualitatif dalam menganalisis permasalahan. Kajian ini akan melakukan sebuah analisis sosial-legal terhadap implementasi kesetaraan dan keadilan gender dalam rangka menjelaskan sebuah kondisi yang pada akhirnya menunjukan urgensi Undang - Undang Kesetaraan dan Keadilan Gender sebagai landasan dalam mengkonsolidasikan seluruh elemen masyarakat di dalam pembangunan Indonesia hari ini dan di masa depan.
\end{abstract}

Kata kunci: Analisis Legal-Sosial, Kesetaraan dan Keadilan Gender, Pembangunan Berkelanjutan

\section{ABSTRACT}

Undeniably the issue of gender has become a very important issue globally. This urgency surfaced with the inclusion of gender issues as one of the main goals of the transformation of the global collective step, namely Sustainable Development Goals (SDGs) in 2015, which became a clear evidence of the growing concern of the world community regarding gender 
equality and polemics (un.org). However, gender equality and justice polemics remain a task far from over for Indonesia, especially when referring to the fact that the role of women in Indonesia still shows various inequalities in their correlation with development holistically. This condition is inseparable from the fact that until now Indonesia does not have a law that comprehensively accommodates the protection of women's rights from forms of discrimination against women, and violations of women's human rights in Indonesia's development. In this context, this study is woven within the framework of the urgency of gender equality and justice in Indonesia's development which demands laws that can become a comprehensive legal umbrella for the implementation of gender equality and justice. Using the approach of the social system, gender, and various concepts available in understanding women and development; and using qualitative methodologies in analyzing problems. This study will carry out a social-legal analysis of the implementation of gender equality and justice in order to explain a condition that ultimately shows the urgency of the Gender Equality and Justice Act as a basis for consolidating all elements of society in Indonesia's development today and in the future.

Key words: Legal-Social Analysis, Gender Equality and Justice, Sustainable Development

\section{Pendahuluan}

Tak dapat disangkal lagi persoalan gender telah menjadi sebuah isu yang sangat penting secara global. Urgensi ini mengemuka dengan masuknya isu gender sebagai salah satu tujuan utama transformasi langkah kolektif global yakni Sustainable Development Goals (SDGs) pada tahun 2015 lampau yang menjadi sebuah bukti nyata semakin kuatnya kepedulian masyarakat dunia terkait polemik kesetaraan dan keadilan gender (un.org). ${ }^{1}$ Ketika meretas pemahaman terkait landasan moral semakin derasnya desakan untuk mengatasi polemik ketimpangan yang dialami oleh perempuan setidaknya ada dua pendapat yang dapat dirujuk sebagai pintu masuk; pertama, di tengah derasnya globalisasi ekonomi sekarang ini, Globalisasi telah menciptakan kesempatan-kesempatan yang sama bagi semua aktor dalam politik dan ekonomi Global untuk satu sama lain (Kusumawardhana, Indra. 2018). Sehingga, problematika terkait diskriminasi antara perempuan dan laki-laki di dalam aktivitas politik, ekonomi, dan sosial secara luas menemukan arti pentingnya. Sedangkan, wanita yang hidup dalam jeruji masyarakat patriakal cenderung menjadi korban eksploitasi dari proses produksi dalam aktivitas ekonomi, fenomena ini paling mencolok terlihat di negara - negara dunia ketiga. (Islam, Saidul dan Hossain, Ismail. 2016). Pendapat kedua dinyatakan oleh Triyuni Soemartono (2014) pada aras nasional yang berpendapat bahwa pembatasan hak perempuan untuk mengekspresikan diri dan mengaktualisasikan dirinya sangat dipengaruhi oleh budaya patriarki yang telah sekian lama tertanam dalam pola pikir masyarakat Indonesia. Perempuan tereksklusi untuk mendapatkan haknya dalam masyarakat, rumah tangga, dan Negara.

Secara holistik jumlah penduduk perempuan di Indonesia 123.948.260 jiwa atau $49,02 \%$ dari penduduk Indonesia yang berjumlah 252,847.629 jiwa, berarti penduduk perempuan hampir separuh jumlah penduduk Indonesia (Direktorat Jenderal kependudukan dan Pencatatan Sipil, Juni 2013). Adapun gambaran proporsi demografis terkait gender di Indonesia berdasarkan hasil Proyeksi 
Penduduk 2010-2035, pada 2015 rasio jenis kelamin penduduk Indonesia adalah sebesar 101, artinya dari seratus penduduk perempuan terdapat 101 penduduk lakilaki di Indonesia. Rasio jenis kelamin ini akan mencapai 100,17 pada 2035, artinya jumlah penduduk laki-laki dan perempuan akan mencapai jumlah yang hampir sama. Namun ironisnya Tingkat Partisipasi Angkatan Kerja (TPAK) perempuan berdasarkan hasil tilikan Satuan Kerja Nasional (Sakernas) Agustus 2014 adalah sebesar 50,22 persen, terpaut sekitar 27 persen dengan TPAK laki-laki yang bernilai 83,05 persen. Angka TPAK ini menunjukkan bahwa dari 100 perempuan usia 15 tahun ke atas, hanya 50 orang yang tersedia untuk berpartisipasi di pasar kerja. ${ }^{2}$

Kondisi tersebut tidak terlepas dari kenyataan bahwa hingga kini Indonesia belum memiliki sebuah undang-undang yang mengakomodasi secara komprehensif tentang perlindungan hak-hak perempuan dari bentuk-bentuk diskriminasi terhadap perempuan, dan pelanggaran hak asasi perempuan dalam pembangunan Indonesia. Walaupun upaya untuk mewujudkan Rancangan Undang - Undang tentang Kesetaraan dan Keadilan Gender (selanjutnya disebut RUU KKG) itu sendiri, sebenarnya telah memiliki dua landasan secara legal yang telah disepakati bersama terkait dengan persoalan Pengarusutamaan Gender (PUG) untuk kemajuan Indonesia, yang dijelaskan oleh Arivia (2002:87) yaitu (1) "Undang - undang Dasar Negara Kesatuan Republik Indonesia 1945 pasal 31 ayat 1: setiap warganegara baik perempuan maupun laki-laki mendapatkan kesempatan setara untuk mengecap pendidikan", (2) Inpres no 9 tahun 2000 merupakan landasan hukum yang kuat untuk melaksanakan PUG khususnya bagi jajaran pemerintah.

Sebenarnya RUU KKG telah menjadi salah satu Rancangan Undang Undang (RUU) yang masuk dalam daftar Program Legislasi Nasional (Prolegnas) Tahun 2014. Namun hingga akhir masa bakti DPR RI periode 2009-2014, RUU ini tidak berhasil dirampungkan pembahasannya, penyebab mengenai tidak usainya pembahasan tersebut salah satunya adalah perbedaan persepsi terkait konsep "gender" di benak berbagai pihak yang terlibat dalam pembahasan tersebut (Akan dibahas lebih jauh dalam pembahasan penelitian ini). Dalam rapat Paripurna terakhir DPR RI periode 2009-2014 RUU ini dikembalikan kepada komisi VIII (Susiana, Sali. 2014). Sedangkan pembahasan RUU KKG telah berlangsung dalam waktu relatif lama dan telah melibatkan banyak stake holder terkait. Adapun secara urgensi; Undang - Undang untuk mengakomodasi kesetaraan dan keadilan gender memiliki muatan strategis untuk bangsa ini. Karena ketika berbicara ketimpangan sosial sebagai ekses dari globalisasi, banyak argumentasi yang menganggap bahwa wanita sangat rentan menjadi objek eksploitasi oleh kekuatan pasar. Seperti yang diungkap oleh Monique Deveaux (2007) bahwa:

Globalization has deepened women's poverty in many parts of the world, in many instances reducing their control over the type and conditions of work, and over the circumstances of their family life and place of abode. As the power of transnational capital has grown, the power of individual citizens to make decisions about important aspects of daily life has shrunk; women workers are often the most readily exploited, often working under informal and illegal conditions (e.g. textile and garment workers in both the global north and south). 
Selaras dengan pendapat tersebut, pemenuhan HAM Perempuan adalah penghormatan, pemenuhan dan perlindungan yang membutuhkan intervensi positif dan langkah tindak pro-aktif berupa legislasi, peraturan per undang-undangan, rancangan (design) kebijakan, alokasi sumber daya, dan program untuk mewujudkan hak-hak tersebut. Intervensi positif dan langkah-langkah pro aktif perwujudan penuh hak asasi manusia termasuk hak asasi perempuan menghendaki bahwa Negara (Eksekutif, Legislatif, Yudikatif dan seluruh masyarakat) mengemban tiga tingkat tanggung jawab: penghormatan, pemenuhan dan perlindungan hak, termasuk penegakannya. Masing-masing tingkat saling terkait, tidak dapat dipisah-pisahkan satu sama lain (Soemartono, Triyuni. 2014; 13).

Bertolak dari seluruh dinamika internal sosio-legal yang terjadi terkait urgensi Undang-Undang yang menjadi payung hukum dalam melindungi kesetaraan dan keadilan gender serta kegagalan pembahasan RUU KKG untuk disahkan menjadi sebuah Undang - Undang. Kegagalan untuk merampungkan RUU KKG pada periode sebelumnya juga tidak terlepas dari berbagai resistensi yang muncul ketika pembahasan tersebut berlangsung sebagai sebuah dinamika dalam proses sosio-legal. Oleh karena itu tulisan ini akan menjawab mengapa UU KKG sangat penting bagi upaya PUG dan peningkatan KKG di lndonesia? Penelitian ini akan fokus menganalisis urgensi Undang - Undang Kesetaraan dan Keadilan Gender untuk Indonesia. Hal yang mendesak untuk dipahami adalah apabila masalah PUG diatur Undang - Undang tersendiri, maka penanganan masalah PUG ini tidak hanya dikelola oleh eksekutif dan legislatif tetapi oleh semua elemen masyarakat sehingga lebih komprehensif. Law may regulate people equally, but people are not equal structurally (Hukum mungkin mengatur masyarakat secara sama, tetapi masyarakat tidaklah setara secara struktural) itulah realitas yang membalut setiap hukum yang diuji manfaatnya di dalam masyarakat yang secara struktur sangat beragam. Terkait isu gender itu sendiri seperti yang telah diungkap dalam latar belakang sangat erat kaitannya dengan struktur masyarakat Indonesia yang membentuk pola pikir setiap individu di dalamnya.

\section{Kerangka Pemikiran}

Patriarki adalah tatanan kekeluargaan yang sangat mementingkan garis turunan bapak (Wulandari, Retno. 2010). Secara etimologi, patriarki berkaitan dengan sistem sosial dimana ayah menguasai seluruh anggota keluarganya, harta miliknya, serta sumber-sumber ekonomi. Ia juga membuat semua keputusan penting bagi keluarga. Dalam sistem sosial, budaya dan juga keagamaan, patriarki muncul sebagai bentuk kepercayaan atau ideologi bahwa laki-laki lebih tinggi kedudukannya dibanding perempuan. Dimana proses terbentuknya sistem sosial yang patriakal tersebut diawali dari rumah sebagai tempat dimana sosialisasi awal dari konstruksi patriaki. Sebagai gambaran sejak seorang anak kecil perempuan dan laki - laki dibedakan dari nama yang diberikan seperti Joko jika laki - laki sedangkan Wati jika perempuan. Namun tidak hanya terhenti dari nama sebagai garis tanda yang membedakan gender seorang manusia namun juga sejak rumah seorang manusia telah belajar apa itu maskulin dan feminin. Jika seorang anak laki - laki maka mainan yang akan diberikan oleh orang tuanya adalah robot, mobil atau senjata 
(pistol atau pedang) sedangkan seorang anak perempuan akan diberikan mainan boneka, rumah, alat - alat memasak.

Perbedaan gender sebetulnya tidak menjadi masalah selama tidak melahirkan ketidakadilan gender. Namun ternyata perbedaan gender baik melalui mitos-mitos, sosialisasi, kultur, dan kebijakan pemerintah telah melahirkan hukum yang tidak adil bagi perempuan. Pada masyarakat patriarki, nilai-nilai kultur yang berkaitan dengan seksualitas perempuan mencerminkan ketidaksetaraan gender menempatkan perempuan pada posisi yang tidak setara. Karena nilai kultural adalah faktor mental yang menentukan perbuatan seseorang atau masyarakat pada lingkup yang lebih luas (Koentjaraningrat, 1974). Dalam cara hidup masyarakat Indonesia sendiri budaya patriarki masih sangat kental. Dalam kehidupan sosial, politik, ekonomi dan hukum nampak ketimpangan dan kondisi asimetris dan subordinatif terhadap perempuan tampak jelas. Dalam kondisi seperti ini proses marjinalisasi yang mengarah pada tindakan eksploitatif pun menjadi ancaman bagi pembangunan masyarakat Indonesia. Eksploitasi tersebut tidak hanya di tataran domestik (Rumah Tangga) namun sudah merasuk pada ranah publik.

Sedangkan istilah gender berasal dari Middle English yaitu 'gendre', yang diambil dari era penaklukan Normandia pada zaman Prancis kuno. Kata 'gender' berasal dari bahasa Latin, genus yang berarti tipe atau jenis. Kedua istilah gendre dan genus, memiliki arti tipe, jenis, dan kelompok. Gender adalah himpunan karakteristik yang membedakan laki-laki dan perempuan. Dalam ilmu-ilmu sosial, kata 'gender' secara khusus mengacu pada konstruksi sosial dan perbedaan kelembagaan, seperti perbedaan peran gender. ${ }^{3}$ H.T.Wilson (1989:2) dalam buku Sex and Gender menyebutkan bahwa gender adalah suatu dasar untuk menentukan pengaruh faktor budaya dan kehidupan kolektif dalam membedakan laki-laki dan perempuan. Sedangkan Hilary.M.Lips (2001:4) dalam buku Sex and Gender: an Introduction mengartikan gender sebagai harapan-harapan budaya terhadap laki-laki dan perempuan. Oakley (1972) dalam Sex, Gender, ond Society mengartikan gender sebagai perbedaan jenis kelamin yang bukan biologis dan bukan kodrat Tuhan. Perbedaan biologis jenis kelamin merupakan kodrat Tuhan, karena secara permanen dan universal berbeda, sedangkan gender adalah behavioral differences (perbedaan perilaku) antara laki-laki dan perempuan yang socially constructed (dikonstruksikan secara sosial), yaitu perbedaan yang bukan kodrat atau bukan ciptaan Tuhan, melainkan diciptakan, baik oleh laki-laki maupun perempuan melalui proses sosial dan budaya yang panjang.

Menurut Tim Studi Wanita Universitas Udayana (2003) ada tiga jenis peran gender sebagai berikut. (1) Peran produktif adalah peran yang dilakukan oleh seseorang, menyangkut pekerjaan yang menghasilkan barang dan jasa, baik untuk dikonsumsi maupun untuk diperdagangkan. Peran ini sering pula disebut dengan peran di sektor publik. (2) Peran reproduktif adalah peran yang dijalankan oleh seseorang untuk kegiatan yang berkaitan dengan pemeliharaan sumber daya manusia dan pekerjaan urusan rumah tangga, seperti mengasuh anak, memasak, mencuci pakaian dan alat-alat rumah tangga, menyetrika, membersihkan rumah, dan lain-lain. Peran reproduktif ini disebut juga peran di sektor domestik. (3) Peran sosial adalah peran yang dilaksanakan oleh seseorang untuk berpartisipasi di dalam kegiatan sosial kemasyarakatan, seperti gotong-royong dalam menyelesaikan beragam 
pekerjaan yang menyangkut kepentingan bersama. Bertolak dari uraian tersebut dapat ditarik sebuah kesimpulan bahwa peran kodrati bersifat statis, sedangkan peran gender bersifat dinamis.

Pembangunan pemberdayaan perempuan telah dilaksanakan lebih dari dua dasawarsa, hasilnya terlihat adanya peningkatan peran dan kedudukan perempuan di berbagai bidang kehidupan. Namun, peningkatan tersebut masih belum sebagaimana diharapkan yaitu terwujudnya keadilan dan kesetaraan antara perempuan dan lakilaki dalam hak dan kesempatan berpartisipasi dan menikmati hasil pembangunan. Perempuan masih tertinggal di berbagai bidang dibanding laki-laki. Kebijakan publik sering diformulasikan dengan mengasumsikan peran perempuan hanya sebagai ibu rumah tangga, sehingga mengurangi hak dan kesempatan perempuan yang akhirnya mengukuhkan bentuk-bentuk ketidaksetaraan dan ketidakadilan Gender di segala bidang pembangunan. Padahal peranan wanita dalam pembangunan adalah hak dan kewajiban yang dijalankan oleh wanita pada status atau kedudukan tertentu dalam pembangunan, baik pembangunan di bidang politik, ekonomi, sosial budaya maupun pembangunan di bidang pertahanan dan keamanan, baik di dalam keluarga maupun di dalam masyarakat. Peranan wanita dalam pembangunan yang berwawasan gender, berarti peranan wanita dalam pembangunan sesuai dengan konsep gender atau peran gender sebagaimana telah dibahas di depan, mencakup peran produktif, peran reproduktif dan peran sosial yang sifatnya dinamis. Dinamis dalam arti, dapat berubah atau diubah sesuai dengan perkembangan keadaan, dapat ditukarkan antara pria dengan wanita dan bisa berbeda lintas budaya (Sudarta, Wayan. 2003).

\section{Parameter Ketimpangan dan Ketidakadilan Gender dalam Sistem Sosial Indonesia}

Memilih terminologi membutuhkan sebuah landasan konseptual yang proper supaya terhindar dari kemelut kerancuan, terutama jika terkait dengan RUU KKG yang pada hakekatnya berupaya memberikan payung hukum terhadap relasi laki-laki dan perempuan di dalam masyarakat. Jika kita merujuk pada tidak seleseinya pembahasan RUU KKG pada prolegnas 2014; salah satu isu yang paling krusial dalam pembahasan tersebut adalah penggunaan istilah "gender". Sebagaimana telah diuraikan sebelumnya, terdapat satu fraksi yang secara tegas dan eksplisit menolak melanjutkan pembahasan RUU KKG selama masih menggunakan istilah "gender" dan mengusulkan istilah "perempuan" untuk menggantikan terminologi tersebut (Susiana, Sali. 2014).

Menurut Mosse (1993), tiga substansi penting yang harus diperhatikan ketika pembahasan mengenai gender pada tataran konseptual lebih penting daripada konsep perempuan dalam konteks pembangunan. Pertama, pembahasan terkait perempuan sebagai suatu kategori memiliki polemik tersendiri. Konsep "posisi perempuan" dalam masyarakat memunculkan kesan bahwa kedudukan perempuan telah memiliki makna yang diterima secara universal di dalam sistem sosial, seolah - olah ada posisi tertentu yang diduduki oleh perempuan yang secara konsensus telah diterima sebagai kelaziman oleh masyarakat. Sedangkan, realitas yang terjadi adalah posisi perempuan di masyarakat sangat beragam, baik secara stratifikasi sosial, kultur maupun etnis . 
Kedua, terminologi gender lebih memiliki modalitas yang kuat secara kegunaannya karena istilah tersebut mencakup peran sosial baik perempuan dan laki-laki. Keterkaitan antara keduanya sangat penting dalam memahami posisi perempuan dan laki - laki serta jenis - jenis hubungan dari keduanya yang merupakan sebuah konsekuensi logis dari pendefinisian perilaku gender secara lazim di masyarakat.. Sebagai contoh, pekerjaan yang dilakukan oleh perempuan dan laki-laki tertentu di dalam masyarakat tidak terlepas dari relasi antara keduanya yang ditetapkan berlandaskan pada kelas, gender dan suku. Kendati demikian, sebagian besar perempuan juga hidup dalam keluarga, dan ikatan dalam keluarga merepresentasikan aspek yang sangat penting terkait bagaimana perempuan menjalani keseharian dalam hidupnya. Bahkan pembuatan keputusan, akses terhadap sumber daya, pembagian kerja serta hubungan di luar keluarga kemungkinan besar merupakan artikulasi dari hubungan gender di dalam sebuah keluarga. ${ }^{4}$

Ketiga, korelasi antara gender dan pembangunan terletak pada kenyataan bahwa setiap insiatif pembangunan dalam aspek apapun akan mempengaruhi kehidupan laki - laki dan perempuan. Oleh karena itu, setiap proyek, program, kegiatan serta aktifitas dalam rangka pembangunan akan mempengaruhi laki - laki dan perempuan. Dikarenakan posisi laki - laki dan perempuan yang berkelindan sangat erat dalam sistem sosial, pembangunan yang dilakukan akan berpengaruh terhadap struktur yang membentuk sistem sosial maka posisi laki - laki dan perempuan juga akan ditentukan dalam dinamika sosial yang terjadi. ${ }^{5}$

Oleh karena itu, argumentasi salah satu fraksi di Parlemen Indonesia yang menolak RUU KKG pada pembahasan di 2014 silam dengan dasar pemikiran bahwa konsep gender tidak mengakar dalam masyarakat Indonesia memang dapat dipahami, karena cara pandang tersebut bersumber pada struktur sistem sosial patriakal di Indonesia yang memunculkan sudut pandang bahwa ketidak-adilan yang terjadi hanya pada sisi perempuan di masyarakat. Padahal telah banyak kajian di dunia ini yang mengungkap bahwa baik laki - laki dan perempuan mengalami dampak - dampak tertentu di dalam arus pembangunan di berbagai negara. Seperti yang diungkap dalam buku Ian Bannon dan Maria C Correia (2006) bahwa globalisasi, perubahan ekonomi, kemiskinan dan perubahan sosial telah melemahkan peran laki - laki secara tradisional yang dianggap sebagai pencari nafkah, kondisi tersebut pada tataran tertentu berakibat pada distorsi perilaku laki - laki yang mencari pengakuan pengakuan maskulinitas melalui berbagai tindakan menyimpang (contoh; praktik seksual yang tidak aman, serta kekerasan dalam rumah tangga), dimana hal tersebut bukan mempengaruhi laki - laki tetapi juga perempuan sebagai pasangannya, keluarga, dan masyarakat secara luas.

Kultur patriarkhi membentuk perbedaan perilaku, status dan otoritas lakilaki dan perempuan di masyarakat kemudian menjadi hierarki gender. Perbedaan biologis antara laki-laki dan perempuan dianggap sebagai awal pembentukan budaya patriarkhi. Masyarakat memandang perbedaan biologis antara keduanya merupakan status yang tidak setara, perempuan yang tidak memiliki otot dipercayai sebagai alasan masyarakat meletakkan perempuan pada posisi lemah. Walby mengatakan bahwa partiarkhi merupakan sistem terstruktur dan praktek sosial yang menempatkan kaum laki-laki sebagai pihak yang mendominasi, melakukan operasi dan mengeksploitasi kaum perempuan. Sistem ini ada dalam dua bentuk yakni (1) 
Private patriarchy (partiarkhi domestik) yakni yang menekankan kerja dalam rumah tangga sebagai steorotipe perempuan, dan; (2) Public patriarchy (patriarkhi publik) yakni yang memberikan stigmatisasi terhadap laki-laki sebagai pekerja di sektor publik yang sarat dengan karakter keras penuh tantangan (Walby, Silvia. 1998: 20).

Potensi untuk terjadinya eksploitasi terhadap kaum perempuan hingga saat ini telah menjadi polemik yang bukan hanya menjadi wacana dalam lingkup negara namun telah menjadi wacana global untuk dapat melakukan sebuah transformasi kolektif dalam rangka menghapus ketidakadilan serta ketidaksetaraan antara antara laki-laki dan perempuan. Memang di tataran Internasional, konsep hak - hak terhadap perempuan telah muncul pada tahun 1975, ketika dimulainya 1st World Conference di Mexico yang ditindak lanjuti dengan munculnya resolusi United Nations pada tahun 1982 yang berbunyi "Women have a vital role to play in the promotion of peace in all spheres of life: In the family, the community, the nation and the world" (un-document. 1982). Pasca berakhirnya perang dingin, sistem internasional mengalami perubahan yang signifikan, konsep globalisasi mengetengah menggantikan konsep internasionalisme yang pada era sebelumnya menjadi spektrum utama di dalam dinamika hubungan internasional (Kusumawardhana, Indra. 2017a). Hal ini setidaknya dijelaskan oleh Indra Kusumawardhana (2017b) di dalam artikelnya sebagai berikut "In reality, international relations are no longer limited to an aggregation of relations between states. Actors at various levels have appeared in the international arena, interacting with one another both horizontally and vertically and continuing building mutually dependent relationships". Isu-isu tradisional yang pada era perang dingin lebih banyak membalut kontestasi politik dunia, setelah globalisasi menjadi spektrum utama, isu-isu non-tradisional seperti kesetaraan dan keadilan gender mendapatkan momentum untuk mengetengah di dalam diskursus hubungan internasional baik akademis maupun praktis.

Aksentuasi isu Kesetaraan dan keadilan gender semakin nyata ketika The 4th World Conference on Women di Beijing tahun 1995 mengidentifikasi beberapa isu kritis gender yang merupakan bentuk keprihatinan dan perlu segera mendapat penanganan, yakni antara lain terbatasnya keikutsertaan perempuan dalam pengambilan keputusan dan terbatasnya lembaga-lembaga serta mekanisme yang dapat memperjuangkan kaum perempuan baik dalam sektor pemerintah maupun non-pemerintah (Nurhaeni, 2009:59). Sedangkan menurut Aurora (2002) tentang hak-hak perempuan yang dideklarasikan oleh United Nations under Convention on the elimination of Discrimination Against Woman (CEDAW) ada 10 (sepuluh) prinsip yang saling berkelindan, tiga diantaranya adalah: (1) Women have the right to the prevention of, and protection from all forms of violence and coercion against their person, their sexuaility, and their individuality; (2) Woman have the right to freely anf fully participate individually or collectively in the political precesses of their communities and nations; Dan (3) Women have the right to the means for assuring their economic welfare and security. Dari deklarasi di atas sangat jelas bahwa kesetaraan dan keadilan gender telah menjadi sebuah Universal Value and Norms dimana perempuan mempunyai hak untuk dilindungi dari berbagai macam kekerasan, secara individu bebas berpartisipasi, membutuhkan tambahan pengetahuan, dipertimbangkan dalam hak-hak hukumnya. Oleh karena itu, 
menimbang keterbatasan ruang dan waktu dalam melakukan kajian, analisis ini akan menguji capaian Indonesia dalam menjalankan 3 (tiga) dari 10 (sepuluh) prinsip CEDAW dengan data - data terbaru terkait prinsip-prinsip tersebut.

\section{Peraturan Perundang-Undangan Terkait Implementasi Konsep Kesetaraan dan Keadilan Gender di Indonesia}

Di Indonesia, konsep kesetaraan dan keadilan gender yang merujuk pada upaya untuk menghilangkan diskriminasi terhadap perempuan baru muncul pada Garis Besar Halauan Negara (GBHN) tahun 1993-1998 (Ditetapkan oleh MPR) yang menyatakan perempuan memiliki hak - hak dan kewajiban - kewajiban yang sama dengan laki - laki. Meskipun Majelis Permusyawarahan Rakyat (MPR) pada waktu itu belum merujuk secara eksplisit pada upaya untuk kesetaraan dan keadilan gender namun hak - hak dan kewajiban - kewajiban yang sama antara laki - laki dan perempuan dapat diartikan telah berupaya mengarah pada konsep kesetaraan dan keadilan gender (Ayun, Dwi Al. 2014). Hal ini ditindaklanjuti dengan memperkenalkan konsep gender equality di dalam Garis Besar Halauan Negara (GBHN) 1999-2004 yang diimplementasikan dengan mengeluarkan Instruksi Presiden No.9/2000 tentang Pengarusutamaan Gender (PUG) dalam pembangunan (Hastuti Dewi, Kurniawati.2007); Berlandaskan pada GBHN tersebut, yang merupakan kehendak politik bangsa Indonesia yang strategis, sebagaimana GBHN periode sebelumnya, bahwa kedudukan perempuan perlu ditingkatkan dengan memperhatikan kodrat, harkat dan martabat perempuan. Komitmen pemerintah, sebagaimana Undang-Undang Nomor 7 tahun 1984 tentang Pengesahan Konvensi Mengenai Penghapusan segala bentuk diskriminasi terhadap wanita (covention on the elemenation of all forms of discrimanation against women), bahwa segala warga negara bersamaan kedudukannya di dalam hukum dan pemerintahan, sehingga segala bentuk diskriminasi terhadap wanita harus dihapuskan karena tidak sesuai dengan Pancasila dan Undang-Undang Dasar tahun 1945 (Soemartono, Triyuni. 2014).

Sayangnya sejak pemerintah menetapkan Undang - Undang No. 10 tahun 2004 mengenai Pembentukan Peraturan Perundang-undangan; MPR sebagai lembaga tertinggi negara tidak dimasukkan dalam hierarki undang - undang dan regulasi di Indonesia. Sehingga konsep terkait hak - hak perempuan akhirnya terletak pada Undang - Undang Dasar Negara Kesatuan Republik Indonesia pasal 28D (3) yang menyatakan bahwa Setiap warga negara berhak memperoleh kesempatan yang sama dalam pemerintahan. Serta Pasal 28H (2) yang berbunyi Setiap orang mendapat kemudahan dan perlakuan khusus untuk memperoleh kesempatan dan manfaat yang sama guna mencapai persamaan dan keadilan. ${ }^{6}$ Dua butir dalam Undang - Undang Dasar tersebut memberikan penekanan pada dua konsep yakni kesetaraan dan keadilan.

Memang pasca reformasi serta demokratisasi Indonesia pada tahun 1999, Hak Asasi Manusia menjadi wacana sangat penting dalam pembangunan Indonesia. Kebebasan - kebebasan yang ditawarkan pada era demokrasi juga memberikan ruang untuk diskursus terkait kesetaraan gender berkembang baik pada tataran akademis maupun praxis dalam bernegara dan berbangsa. Namun pasca demokratisasi, setiap warga negara tidak hanya menikmati hak dan kebebasannya, 
tetapi juga memikul tanggung jawab bersama dengan warga negara lainnya untuk kepentingan bersama di masa depan. Namun menurut Budi Winarno (2008) ada banyak problematika yang harus diseleseikan oleh Indonesia jika ingin meningkatkan kualitas kehidupan berbangsa dan bernegara di Indonesia. Salah satunya adalah masalah pemberdayaan perempuan, dengan tujuan agar perempuan mendapatkan ruang artikulasi publik yang memadai, kultur patriarki dalam masyarakat harus diubah. Marginalisasi kaum perempuan diakibatkan oleh struktur sosial yang tidak adil dan bias gender (Winarno, Budi. 2008).

Namun, dari 11 Undang - Undang yang ditetapkan oleh Dewan Perwakilan Rakyat (DPR) bersama dengan Presiden berkaitan dengan hak - hak perempuan dalam kerangka mengakomodasi urgensi kesetaraan dan keadilan gender; hanya enam dari keseluruhannya yang memiliki manfaat praktis terhadap perempuan. Di antara Peraturan Perundang - undangan yang mengandung muatan perlindungan hak asasi perempuan adalah: Undang-Undang Nomor 39 Tahun 1999 tentang HAM, Undang-Undang Nomor 23 Tahun 2004 tentang Penghapusan KDRT, UndangUndang Nomor 12 Tahun 2006 tentang Kewarganegaraan, Undang-Undang Nomor 21 Tahun 2007 tentang Pemberantasan Tindak Pidana Perdagangan Orang, dan Undang-undang Politik (UU No. 2 Tahun 2008 dan UU No. 42 Tahun 2008). Kemudian Kepres No. 181 Tahun 1998 tentang Pembentukan Komisi Nasional Anti Kekerasan terhadap Perempuan atau Komnas Perempuan yang diubah dengan Perpres Nomor 65 Tahun 2005 (Kania, Dede. 2015). Serta Undang - Undang Republik Indonesia Nomer 8 Tahun 2012 terkait Pemilihan Anggota Dewan Perwakilan Rakyat, Dewan Perwakilan Rakyat Daerah serta Dewan Perwakilan Daerah yang memperkuat keterwakilan perempuan di parlemen.

Sedangkan peraturan yang menjadi dasar untuk memperkuat peran perempuan dalam pembangunan Indonesia ada pada Inpres Nomor 9 Tahun 2000 tentang Pengarustamaan Gender (PUG). Inpres ini menjadi dasar adanya upaya berperspektif gender bagi seluruh kebijakan dan program pembangunan nasional, tanpa kecuali. Baik kebijakan di pusat maupun di daerah haruslah berperspektif gender, apabila tidak maka kebijakan tersebut harus diganti. Berlandaskan seluruh instrumen hukum yang tersedia tersebut penelitian ini memiliki modalitas untuk melakukan tilikan lebih mendalam terkait implementasi dari seluruh instrumen yang tersedia merujuk pada prinsip CEDAW.

Prinsip 1: Women have the right to the prevention of, and protection from all forms of violence and coercion against their person, their sexuaility, and their individuality

Hampir dua dekade setelah reformasi serta munculnya berbagai undang undang dan regulasi ternyata kondisi kesetaraan dan keadilan gender di Indonesia tidak mengalami perubahan. Berdasarkan laporan Komisi Nasional Perempuan pada tahun 2011 (Gambar di bawah) mengungkap bahwa tindakan kekerasan terhadap perempuan terus mengalami kenaikan dari tahun ketahun; Di tahun 2001 ada pada angka 3.169 kasus, kemudian meningkat menjadi 5.163 kasus di tahun 2002. Selanjutnya pada tahun 2003 kembali naik 20\% menjadi 7.787 kasus. Melambung dua kali lipat pada tahun 2004 menjadi 14.020 kasus. Di tahun 2005, tindakan 
kekerasan tersebut terus meningkat menjadi 20.391 kasus dan trend kenaikan tersebut berlanjut pada tahun 2006 pada angka 22.512 kasus. Sedangkan pada 2007, kasus tindakan kekerasan terhadap wanita kembali meningkat menjadi 25.522 kasus yang berlipat ganda pada tahun 2008 pada angka 54.425 kasus. Hingga pada titik kenaikan tertinggi di tahun 2009 pada angka 143.586 kasus dan meningkat sedikit pada tahun 2010 menjadi 105.103 kasus. Dengan kata lain, menggunakan tolak ukur bentang waktu 10 tahun (1 dekade) semakin banyak perempuan Indonesia menjadi korban kekerasan dengan angka yang memprihatinkan.

Gambar. 1

Tingkat Terjadinya Kekerasan Terhadap Perempuan dari 2001 - 2010

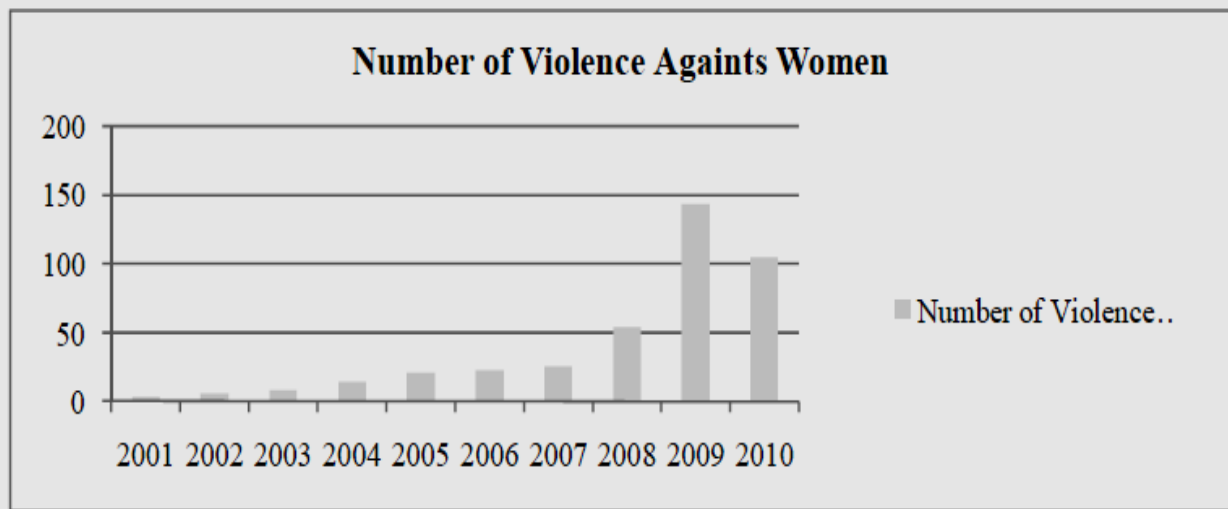

Sumber: Al Uyun, Dhia. 2014. Women's Right in Indonesian Constitution, International Journal of Humanities and Social Science, Vol.4, No.8 (1); June 2014

Bahkan merujuk pada gambaran kondisi terkini, angka tersebut tidak kunjung membaik dan terus meningkat. Bahkan pada tahun 2015 Komisioner Komisi Nasional Perempuan Indonesia menyatakan bahwa saat ini Indonesia sedang dalam kondisi darurat kekerasan terhadap perempuan. Data Komnas Perempuan pada 2014 menunjukkan jumlah kekerasan terhadap perempuan sebanyak 293.220 kasus. Jumlah ini meningkat dibandingkan tahun 2013 sebanyak 279.688 kasus. $^{7}$ Jika membandingkan dengan kondisi sebelumnya telah meningkat lebih dari dua kali lipat dari tahun 2010. Lebih lanjut lagi pola yang terjadi selama ini, masih didominasi kekerasan dalam rumah tangga dan relasi personal sebanyak 68 persen, dan kekerasan yang terjadi dalam komunitas sebanyak 30 persen. Ini menunjukkan rumah dan lingkungan seperti tempat kerja, masih tidak aman bagi perempuan, bahkan pola yang terjadi selama ini tidak hanya terbatas pada tataran kekerasan domestik dan relasi individu namun juga kekerasan di ranah kebijakan negara seperti tes keperawanan polisi, larangan adopsi dan kasus pekerja migran (CATAHU, Komnas Perempuan. 2015).

Prinsip 2: Woman have the right to freely anf fully participate individually or collectively in the political precesses of their communities and nations 
Sirimavo Bandaranaike tercatat dalam tinta sejarah politik dunia ketika menjadi perempuan pertama yang menjadi Perdana Menteri di Sri Lanka di tahun $1960 .^{8}$ Sejak saat kurang dari 80 perempuan dari belahan dunia lain mencapai posisi eksekutif baik sebagai menteri, perdana menteri atau presiden. Menurut UNDP; Di tahun 1990 setidaknya ada 26 perempuan yang menempati posisi eksekutif di kabinet-kabinet berbagai negara di dunia, dimana angka tersebut naik menjadi 37 perempuan di tahun 2000-yaitu mengalami kenaikan tiga kali lipat dibanding tahun-tahun sebelumnya, yaitu 60-an, 70-an, dan 80-an (UNDP, Gender Leadership in Executive Report, 2013). Kendati demikian terdapat banyak negara yang masih bergulat dengan tantangan untuk meruntuhkan "atap kaca" (kerap disebut sebagai glass ceiling). ${ }^{9}$

Dikarenakan peran perempuan untuk meningkatkan kemampuan untuk mengorganisasi diri serta terlibat dalam proses politik terkait pembangunan sebuah negara sangat luas. Maka tinjauan ini membagi narasinya dalam dua bagian (1) Kehadiran perempuan di Parlemen sebagai representasi keterwakilan aspirasi politik terkait kesetaraan dan keadilan gender dalam proses pembahasan berbagai undang undang di badan legislatif sebuah negara, (2) Kemudian keterlibatan perempuan dalam pemerintahan eksekutif; birokrasi atau institusi pemerintahan yang merupakan aktor penting dalam kehidupan masyarakatnya. Apalagi di negara berkembang, termasuk Indonesia, birokrasi menjadi akar tunjang utama dalam pembangunan bangsa. Segenap kepentingan dan kebutuhan warga seringkali sangat tergantung kepada keberadaan birokrasi.

Di Indonesia, Salah satu kemajuan yang dicapai dalam hal meningkatkan partisipasi perempuan di parlemen adalah Undang-Undang (UU) Nomor 8 tahun 2012 tentang Pemilihan Umum dimana terdapat enam Pasal yang mengatur mengenai $30 \%$ keterwakilan perempuan dalam Pemilu.yang harus dipenuhi oleh masing partai politik peserta pemilu. ${ }^{10}$ Tindakan Khusus Sementara (Affirmative Action), yang diistilahkan dengan keterwakilan perempuan; menurut Ani Widyani Soetjipto (2005) mendefinisikan secara umum affirmative action sebagai tindakan pro-aktif untuk menghilangkan perlakuan diskriminasi terhadap satu kelompok sosial yang masih terbelakang.

Menurut studi United Nations Division for the Advancement of Women (UNDAW), suara perempuan, khususnya dalam menunjukkan dan memperjuangkan nilai-nilai, prioritas, dan karakter khas keperempuanan baru diperhatikan dalam kehidupan publik apabila mencapai minimal 30-35 persen (Karl, 1995: 63-64). Harapan dari diperkuatnya Undang - Undang yang menjamin kesempatan perempuan untuk maju menjadi calon anggota legislatif di parlemen adalah mampu mendongkrak partisipasi politik perempuan dalam memperjuangkan nasibnya di parlemen; menurut data Daftar Calon Tetap (DCT) Pemilu 2014, partai - partai yang bersaing untuk mendapatkan kursi di parlemen telah berhasil memenuhi kuota $30 \%$ sesuai dengan Undang - Undang yang berlaku. Tentunya hal tersebut tidak lepas dari usaha pemerintah untuk meningkatkan representasi perempuan di ranah legislatif. Hal ini dikarenakan dengan adanya UU No. 8 Tahun 2013 dan beberapa Peraturan Komisi Pemilihan Umum (PKPU), berhasil memaksa partai politik untuk memenuhi kuota perempuan (minimal $30 \%$ ) serta mengakomodasi prinsip 
affirmative action dan zipper system yang menjamin keterwakilan perempuan di parlemen.

Namun demikian, meskipun sudah ada kebijakan khusus untuk meningkatkan representasi perempuan dalam partai politik dan legislatif sebesar 30 persen. Justru ironisnya proporsi tersebut mengalami penurunan dari 18,2 persen pada tahun 2009 menjadi 17,3 persen di tahun 2014. Padahal, kandidat perempuan yang mencalonkan diri dan masuk dalam daftar pemilih dari partai politik mengalami peningkatan dari 33,6 persen tahun 2009 menjadi 37 persen pada 2014. Pada Pemilu Legislatif tahun 2014, ternyata hanya mampu menghasilkan keterwakilan perempuan di legislatif sebanyak 97 kursi (17,32 persen) di DPR, 35 kursi (26,51 persen) di DPD, dan rata-rata 16,14 persen di DPRD serta 14 persen di DPRD kabupaten/kota (Beritasatu.com. 2014). ${ }^{11}$ Sedangkan menurut lembaga Kajian Politik Universitas Indonesia melaporkan bahwa hanya perwakilan di level DPRD Kabupaten/Kota yang mengalami peningkatan dibandingkan dengan hasil pemilu di 2009. Seolah - olah ada jarak antara realitas meningkatnya calon anggota berjenis kelamin perempuan dengan persepsi masyarakat untuk memberikan suaranya kepada kandidat perempuan di parlemen.

Adapun untuk DPD RI pada periode 2014-2019; proporsi antara anggota yang terpilih antara perempuan dan laki - laki juga telah mengalami penurunan sebesar 3\% (persen). Eksistensi DPD RI yang memiliki peran strategis dalam melibatkan aspirasi daerah dalam menentukan halauan politik dan pranata di aras nasional ${ }^{12}$, tentunya memiliki fungsi sesuai dengan wewenang konstitusionalnya dalam meperjuangkan berbagai isu kemasyarakatan. Dalam konteks isu - isu yang diperjuangkan, DPD RI telah menyusun 13 (Tiga Belas) isu strategis yang diantaranya perwujudan kesejahteraan dan keadilan gender. Sudah seharusnya dengan perwujudan keadilan gender oleh lembaga legislatif ini, harapannya pembangunan responsive gender bisa dilaksanakan dengan baik. Hal ini ditandakan pula dengan meningkatnya keterwakilan perempuan di DPD RI tahun 2009-2014 mencapai $28,80 \%$, suatu angka yang jauh lebih bagus jika dibandingkan perolehan anggota perempuan DPR RI . Bahkan tahun ini DPD RI kembali mencatat angka yang lebih tinggi dari seluruh lembaga legislatif yakni 25,80\% (26,51 jika merujuk pada data beritasatu.com).

Salah satu alasan mengapa DPD RI memiliki catatan komposisi anggota terpilih berjenis kelamin perempuan yang lebih baik dibandingkan seluruh lembaga legislatif adalah karena pencalonan perempuan di DPD memang tidak melalui partai politik. Selain itu, ada "tren politik" yang sangat kondusif, di mana pemilih kemungkinan lebih menyukai untuk memilih perempuan bila tidak melalui partai politik. Sekalipun demikian, secara umum terdapat data dan fakta yang menginformasikan adanya isu pokok bahwa "perempuan kurang mendapat akses berperan dalam struktur kekuasaan dan proses pengambilan keputusan" mulai dari aras keluarga sampai pada lembaga-lembaga politik dan penentu kebijakan publik" (Soemartono, Triyuni. 2014).

Hal tersebut memberikan gambaran bahwa Undang-Undang No. 2 Tahun 2008 tentang Partai Politik yang terakhir telah diubah dengan Undang-Undang 2 Tahun 2011 tentang Partai Politik dan Undang-Undang No. 10 Tahun 2008 tentang Pemilihan Umum Anggota DPR, DPD, dan DPRD yang terakhir diganti dengan 
Undang-Undang No. 8 Tahun 2012 tentang Pemilihan Umum Anggota DPR, DPD, dan DPRD (Karnia, Dede. 2015). Ternyata masih belum mampu meningkatkan kesempatan untuk perempuan mengartikulasikan suaranya di parlemen. Padahal Undang-undang ini merumuskan aturan tentang bentuk diskriminasi positif (affirmative action) berupa kuota $30 \%$ bagi perempuan di ranah politik Indonesia.

Bagaimana dengan keterwakilan (fisik) perempuan di dalam eksekutif? Meskipun keterlibatan perempuan dalam kabinet setiap tahunnya meningkat pasca reformasi namun ketimpangannya masih sangat jauh antara perempuan dan laki laki. Bahkan jika kita memperhatikan lebih jauh lagi; gambaran serupa juga terjadi dalam cakupan komposisi perempuan yang terpilih sebagai kepala daerah bahkan kepala desa di Indonesia. Sejak Kabinet Gotong Royong hingga Kabinet Indonesia Bersatu II; terjadi peningkatan komposisi antara laki - laki dan perempuan dari angka 2 (dua) di era Kabinet Gotong Royong kemudian belipat ganda menjadi 4 (empat) di Kabinet Indonesia Bersatu I dan meningkat kembali menjadi 5 (lima) di Kabinet Indonesia Bersatu II. Bahkan di era Kabinet Kerja sekarang ini kembali mencatat peningkatan signifikan dengan dipercayanya 8 (delapan) orang perempuan untuk menduduki jabatan menteri; terbanyak dalam sejarah komposisi Kabinet di Indonesia (Bertambah satu menjadi sembilan ketika Sri Mulyani diangkat menjadi Menteri Keuangan). ${ }^{13}$

Trend tersebut menunjukan bahwa perempuan Indonesia semakin percaya diri dan mampu menunjukan potensinya untuk memimpin instansi pemerintah dalam turut serta membangun negara Indonesia. Meskipun komposisi tersebut masih jauh jika dibandingkan dengan negara Finlandia yang mampu meningkatkan kapasitas perempuannya hingga tataran luar biasa sehingga komposisi laki - laki dan perempuan dalam pemerintahan di Helsinki memiliki 12 (dua belas) menteri perempuan dari 20 (dua puluh) keseluruhan jabatan menteri di Finlandia. ${ }^{14}$ Namun peningkatan komposisi tersebut dapat dianggap sebagai prestasi dalam memperjuangkan kesetaraan dan keadilan gender di Indonesia.

Dalam pilkada serentak 9 Desember 2015, jumlah keterpilihan perempuan calon kepala dan wakil kepala daerah tercatat tidak mencapai separuh dari jumlah pencalonan perempuan. Data Komisi Pemilihan Umum per 30 Desember 2015 menunjukkan, dari 123 calon perempuan, hanya terdapat 46 perempuan kepala daerah dan wakil kepala daerah yang terpilih. Sebanyak 24 perempuan terpilih sebagai kepala daerah dan 22 terpilih sebagai wakil kepala daerah (Kompas.com, 2016). Sedangkan jika melihat kondisi jumlah dan persentase aparat birokrasi (Pegawai Negeri Sipil/PNS) perempuan telah mencapai nominal yang cukup signifikan. Perbandingan jumlah PNS menurut jenis kelamin pada tahun 2013 tidak menunjukkan kesenjangan yang berarti. Mengacu data dari Badan Kepegawaian Negara (BKN), dari 4.362.805 PNS, sebanyak 2.102.197 atau 48,18\% yang berjenis kelamin perempuan dan sisanya sebesar $2.260 .608(51,82 \%)$ laki-laki. Namun, kesenjangan tampak secara mencolok saat memperhatikan proporsi pejabat struktural di institusi birokrasi. Gambaran yang disajikan oleh data terkait permasalahan kesenjangan di dalam proporsi pejabat struktural sangat penting maknanya jika Indonesia ingin meningkatkan kesetaraan dan keadilan gender dalam konteks partisipasi perempuan di lingkup pelbagai institusi publik di negara ini. 
Hasil penelitian Puskapol UI (2012) menunjukkan proporsi laki-laki dan perempuan di jabatan struktural di 34 kementerian cenderung timpang. Hanya $22,38 \%$ jabatan struktural yang diisi oleh perempuan. Proporsinya semakin menunjukan ketimpangan ketika ditinjau berdasarkan jenjang jabatan struktural yang diduduki. Proporsi terbesar perempuan pejabat struktural berada pada jenjang bawah, yaitu di eselon III dan IV. Sedangkan pada jenjang tingkat atas hanya ada 1 perempuan dari 10 pejabat eselon I. Padahal, pejabat struktural pada jenjang tertinggi memiliki kesempatan yang besar dalam proses pembuatan kebijakan strategis di pemerintahan. Kecenderungan yang sama juga terjadi di daerah. Kajian mengenai pemetaan isu gender di bidang politik di Provinsi Sumatera Selatan menunjukan hasil serupa.

Berdasarkan seluruh narasi yang telah dibangun di atas dapat ditarik kesimpulan bahwa saat ini Indonesia masih sangat jauh dalam implementasi kesetaraan dan keadilan gender di berbagai sektor terkait keterlibatan perempuan dalam proses politik yang menentukan komunitasnya dan negaranya. Seperti yang dilansir oleh laporan Asian Development Bank terkait partisipasi perempuan dalam penentuan kebijakan publik pada tahun 2015 bahwa:

Women's participation in public decision making remains low. Women won only 17\% of the 555 national parliamentary seats in the 2014 elections, a decline from the previous election. The 2014 Global Gender GAP Report ranks Indonesia 95th out of 125 countries in terms of the number of female "legislators, senior officials and managers", significantly below the Philippines (5th). The government has made efforts to increase women's political participation, including provisions in the 2008 electoral laws requiring a minimum quota of $30 \%$ of female candidates in each political party participating in the elections. Key reasons cited for the low percentage of women elected are: female candidates lack political experience, networking, and financial support; and the continuing preference for male candidates by many voters as a result of prevailing cultural perceptions of men's and women's roles and capacities (ADB, 2015).

Prinsip 3: Women have the right to the means for assuring their economic welfare and security

Ketimpangan yang nampak dalam sistem sosial yang ada di Indonesia tidak hanya terkait rasa aman dari ancaman bersifat kekerasan mental maupun fisik semata dan keterlibatan dalam proses politik dalam menentukan arah komunitas maupun negara. Pada aspek yang berkelindan langsung dengan pembangunan ekonomi Indonesia juga nampak ketimpangan dan ketidak adilan yang sangat tajam. Pada aspek ekonomi terdapat enam artikel yang mengejawantahkan corak ekonomi Indonesia yang bernafaskan demokrasi yakni Pasal 27(2), 28A, 28D (2), 28H (2);(3);(4), Pasal 33 dan Pasal 34 (1) dan (2) dari Undang - Undang Dasar Negara Republik Indonesia. 
Sekali lagi jika fokus pada salah satu indikator PUG yakni Rasio Kesempatan Kerja Terhadap Penduduk Usia Kerja di Indonesia. Masih ada disparitas yang jauh antara kesempatan kerja untuk perempuan dibandingkan kesempatan kerja untuk laki - laki. Pada tahun 2011 rasio kesempatan kerja untuk laki - laki ada pada persentase 78.32 sedangkan perempuan hanya 45.34\%. Di tahun 2014, angka tersebut tidak banyak berubah yakni $78.27 \%$ untuk laki - laki sedangkan untuk perempuan adalah 47.08. Perlu diperhatikan bahwa rasio kesempatan kerja merupakan gambaran kesetaraan dan keadilan terkait akses setiap individu (laki-laki dan perempuan) di Indonesia dalam berkontribusi dalam dinamika pembangunan Indonesia secara menyeluruh. Disparitas yang cukup jauh tersebut diperkuat lagi dengan Tingkat Kesenjangan Upah Gender di Indonesia yang terus meningkat dari tahun ke tahun.

Dalam konteks rendahnya akses perempuan dalam pasar tenaga kerja serta ketimpangan dan ketidakadilan dalam perlakuan terhadap perempuan di bidang ekonomi. Global Gender Gap 2014 melaporkan bahwa meskipun tingkat unemployment rate untuk perempuan telah menurun dari $9 \%$ menjadi $6,8 \%$ pada tahun 2012, namun angka tersebut masih jauh lebih tinggi dari laki - laki (5,8\%). Sedangkan Asian Development Bank (ADB) terkait Indonesia menyatakan bahwa "Limited access to training, gender segregation in the labor market, as well as family responsibilities and childcare, are the key factors that limit women's engagement in the labor market" (ADB, 2015). Merujuk pendapat tersebut dapat disimpulkan bahwa pemberdayaan terhadap wanita yang lemah membuat wanita memiliki keterbatasan dalam memilih partisipasinya dalam arus pembangunan Indonesia.

\section{Urgensi UU KKG Dalam Mendukung Pembangunan Berkelanjutan di Indonesia}

Upaya untuk memberdayakan perempuan dalam pembangunan telah dilakukan melalui berbagai pendekatan pembangunan yang ditujukan untuk meningkatkan peran perempuan dalam pembangunan. Pembangunan adalah suatu perubahan perilaku (kognisi, efeksi, dan keterampilan) positif yang akan membawa kemanfaatan bagi orang banyak yaitu, masyarakat secara keseluruhan (Nimrah, Siti \& Sakartia, 2015). Jangan sampai Indonesia abai dalam memperhatikan sejarah, Pembangunan atau Development dahulu telah menjadi sebuah retorika yang sangat kuat pada era rezim orde baru dengan jargon Trilogi Pembangunan: Stabilitas Nasional yang dinamis, Pertumbuhan ekonomi Tinggi dan Pemerataan pembangunan dan hasil - hasilnya. Dimana model Pembangunan tersebut turut memiliki andil semakin tajamnya disparitas terkait kesetaraan dan keadilan gender di Indonesia melalui berbagai segregasi peran antara laki - laki dan perempuan dengan adanya berbagai organisasi seperti Pembinaan Kesejahteraan Keluarga (PKK) dan Dharma Wanita (Siahaan, Asma Yanty. 2003). Ternyata ketika pada akhirnya mengalami kerontokan sistem moneter dikarenakan tekanan - tekanan baik eksternal maupun domestik hingga akhirnya mewujud dalam krisis multidimensi di tahun 1998, seketika pada waktu krisis tersebut perempuan menjadi pihak yang paling menjadi korban dari runtuhnya perekonomian Indonesia. 
Pertumbuhan ekonomi Indonesia yang mendapatkan pujian setinggi langit oleh Bank Dunia (World Bank) sebagai salah satu Asian Economic Miracle (Hadi, Syamsul. 2005). Ternyata pada tahun 1997 mulai mengalami masalah dikarenakan ketergantungan terhadap utang luar negeri, kegagalan manajemen ekonomi makro, korupsi dan kesalahan dalam mengimplementasikan kebijakan - kebijakan dari International Monetary Fund (IMF) yang akhirnya malah menghancurkan perekonomian Indonesia hingga berujung pada terjadinya krisis ekonomi-politik (Harvie, 2000; Hill, 2000). Ternyata krisis tersebut memiliki dampak yang luar biasa terhadap merosotnya kualitas hidup perempuan di Indonesia. Disparitas gender yang sudah mulai semakin dipersempit dengan adanya kebijakan wajib belajar 9 (sembilan) tahun, dan hampir sudah dapat dieliminasi di tahun 1997; kembali melebar pasca krisis yang terjadi (JICA, 1999).

Laporan UNDP menyatakan bahwa angka perempuan yang memiliki penghasilan di bawah garis kemiskinan berlipat ganda dari $11 \%$ menjadi $22 \%$ di Indonesia pada tahun 1998, upah untuk perempuan merosot menjadi sepertiga dari upah laki - laki. Oleh karena itu, perempuan terpaksa untuk menerima jam kerja yang lebih lama untuk dapat memenuhi kebutuhan rumah tangga (UNDP, 2001). Dapat dikatakan perempuan di Indonesia pada waktu itu menjadi pihak yang mendapat respon penurunan kualitas hidup yang paling keras. Hal tersebut tidak terlepas dari dikotomi perempuan sebagai sosok ibu yang memiliki tugas utama yakni "women's primary role as mothers is to look after her family, a group, a class, a company or the state, without demanding power or prestige in return (Nieuwenhuis 1987)". Dimana Suryakusuma (1996) menyebut bahwa cara orde baru membenamkan ideologi "stateibuism" adalah dengan mengartikulasikan definisi perempuan sebagai 'appendages and companions to their husbands, as procreators of the nation, as mothers and educators of children, as housekeepers, and as members of Indonesian society'. Bertolak dari pengalaman tersebut, sangat penting untuk memperhatikan realitas sejarah yang terjadi terkait keadilan dan kesetaraan gender di Indonesia. Untuk itu memahami pemberdayaan perempuan harus memperhatikan sensitivitas yang dalam agar tidak dilakukan secara asal dan dangkal sehingga malah semakin mempertajam ketimpangan di antara perempuan dan laki laki sebagai anggota masyarakat. Oleh karena itu, Undang - Undang Kesetaraan dan Keadilan Gender menjadi sangat penting jika ingin mempercepat pencapaian persamaan substantif serta kesempatan yang sama antara perempuan dan laki - laki dalam menikmati hak - hak sipil, politik, ekonomi, sosial, dan budaya.

Salah satu aspek yang harus diperhatikan adalah kapasitas perempuan dalam bersaing untuk dapat bekerja di berbagai bidang secara maksimal. Studi dari Julie H. Gallaway dan Alexander Bernasek (2016) terhadap angkatan kerja Indonesia mengungkap data empiris yang dianalisis melalui jumlah sampel penelitian 8.654 pekerja laki - laki dan perempuan. Kajian tersebut menunjukan bahwa lebih dari $70 \%$ pekerja yang diteliti bekerja di tiga kategori besar yakni: sektor agrikultur (41\%), sektor penjualan (18\%) dan sektor produksi-konstruksi (12\%). Sedangkan dari kategori tersebut ketika melihat distribusi serta komposisi berdasarkan gender maka nampak data bahwa perempuan kebanyakan berkarya di empat tempat yakni sektor agrikultur (1.404), penjualan (912), proses produksi (411), dan jasa (272). Dimana ke-empat sektor tersebut tidak terlalu membutuhkan literasi bahkan 
pendidikan yang tinggi. Sedangkan di sektor profesional yang membutuhkan literasi dan pendidikan tinggi hanya 36 perempuan yang berkarya di profesi tersebut.

Data tersebut memberikan gambaran bahwa pemberdayaan masih sangat memiliki potensi untuk ditingkatkan demi tercapainya kesetaraan dan keadilan gender. Namun ketiadaan Undang - Undang Kesetaraan dan Keadilan Gender membuat upaya meningkatkan kontribusi perempuan dalam pembangunan kurang kuat. Selama ini strategi pengarus utamaan gender berlandaskan pada Inpres Nomor 9 Tahun 2000 m eliputi: (1) Perencanaan, termasuk di dalamnya perencanaan yang responsif gender/gender budgeting; (2) Pelaksanaan; dan (3) Pemantauan dan Evaluasi. Sedangkan pada tataran yang lebih rendah, dasar hukum pelaksanaan PUG diatur dalam Keputuran Menteri Dalam Negeri Nomor 15 Tahun 2008 tentang Pedoman Umum Pelaksanaan Pengarusutamaan Gender dalam Pembangunan di daerah yang kemudian dilakukan pembahuruan dengan terbitnya Peraturan Menteri Dalam Negeri Nomor 67 Tahun 2011.

Dikarenakan implementasi PUG membutuhkan dukungan anggaran yang responsif gender. Melalui Peraturan Kementerian Keuangan Nomor 119 Tahun 2009 tentang Petunjuk Penyusunan Penelaahan Rencana Kerja dan Anggaran Kementerian Negara/Lembaga dan Penyusunan, Penelaahan, Pengesahan, dan Pelaksanaan Daftar Isian Pelaksanaan Anggaran Tahun Anggaran 2010; tindak lanjut dari seluruh instrumen peraturan tersebut adalah sebanyak 7 (tujuh) Kementerian didorong untuk menerapkan Anggaran Responsif Gender (ARG) ke dalam program dan kegiatan masing-masing Kementerian, yaitu: Kementerian Keuangan, Kementerian Pertanian, Kementerian Pendidikan Nasional, Kementerian Kesehatan, Kementerian Pekerjaan Umum, Kementerian Pemberdayaan Perempuan dan Perlindungan Anak; dan Badan Perencanaan Pembangunan Nasional. Serta untuk mempercepat pelaksanaan PUG, juga telah diterbitkan Surat Edaran mengenai Strategi Nasional Percepatan Pengarusutamaan Gender melalui Perencanaan dan Penganggaran yang Responsif Gender (Susiana, Sali. 2014).

Pada kenyataaannya sudah berbagai macam perundang-undangan dikeluarkan pemerintah sebagai payung hukum untuk menjamin berjalannya konsep kesetaraan dan keadilan gender; tidak hanya di tataran nasional namun diharapkan mampu menderas hingga dilaksanakan di daerah. Tetapi permasalahan / kendala yang dihadapi masih menghadang perkembangan pergerakan perempuan untuk pembangunan yang responsive gender. Dalam konteks permasalahan tersebut Triyuni Soemartono (2014) dalam bukunya "Peran Pemerintah Dalam Pemberdayaan Perempuan" telah memberikan elaborasi permasalahan yang dihadapi dalam pelaksanaan pengarusutamaan gender dalam pembangunan adalah sebagai berikut: (1) masih rendahnya kualitas hidup dan peran perempuan, yang antara lain, disebabkan oleh terjadinya kesenjangan gender dalam hal akses, manfaat, dan partisipasi dalam pembangunan, serta penguasaan terhadap sumber daya, terutama di bidang politik, jabatan-jabatan publik, dan di bidang ekonomi, baik antar-provinsi maupun antarkabupaten/kota; serta rendahnya kesiapan perempuan dalam mengantisipasi dampak perubahan iklim, krisis energi, krisis ekonomi, bencana alam dan konflik sosial, serta terjadinya penyakit. (2) masih rendahnya perlindungan terhadap perempuan dari tindak kekerasan, yang ditandai dengan maraknya kasus-kasus kekerasan terhadap perempuan yang belum diiringi 
dengan peningkatan kuantitas dan kualitas layanan terhadap para korban tindak kekerasan, masih terdapat ketidaksesuaian antarproduk hukum yang dihasilkan, termasuk antara produk hukum yang dikeluarkan oleh pemerintah pusat dengan daerah berkaitan dengan perlindungan terhadap perempuan. (3) masih lemahnya kelembagaan pengarusutamaan gender di Indonesia. Angka GDI (Gender-related Development Index) mengukur pencapaian dari dimensi dan indikator yang sama dengan HDI (Human Development Index), namun dengan memperhitungkan kesenjangan pencapaian antara perempuan dan laki-laki. GDI adalah HDI yang disesuaikan oleh adanya kesenjangan gender, sehingga selisih yang semakin kecil antara GDI dan HDI menyatakan semakin kecilnya kesenjangan gender. Berdasarkan Indonesia Human Development Report 2014, angka HDI 0,684 dan angka GDI 0.927. Ketimpangan antara angka HDI dibandingkan dengan angka GDI menunjukkan, bahwa keberhasilan pembangunan sumber daya manusia secara keseluruhan belum sepenuhnya diikuti dengan keberhasilan pembangunan gender, atau masih terdapat kesenjangan gender. Ukuran lain dalam pembangunan pemberdayaan perempuan adalah Gender Empowerment Measurement (GEM), Angka GEM Indonesia pada tahun 2005 adalah 0,40 kemudian pada tahun 2013 menjadi 0,52. Angka tersebut adalah terendah dari ASEAN-5 (Indonesia, Malaysia, Filipina, Singapura dan Thailand). GEM di Indonesia berkembang jauh di bawah HDI Indonesia dari tahun ke tahun. Dengan begitu menunjukan bahwa kesetaraan dan keadilan gender dalam aspek ekonomi dan politik berjalan sangat lambat.

Data empiris menunjukan bahwa HDI, GDI dan GEM Indonesia dibandingkan dengan capaian negara - negara ASEAN sejak tahun 2005 hingga tahun 2013 (Bangun, W. 2016). Dimana meskipun seluruh negara - negara ASEAN masih belum mencapai numerik 1 terkait berbagai indikator kesetaraan dan keadilan Gender. Namun Indonesia masih jauh di bawah rata - rata pencapaian kesetaraan dan keadilan gender. Situasi ini menurut Bank Dunia rawan terjadinya kondisi dimana perempuan kehilangan kesempatan untuk mendapatkan pendapatan rumah tangga, dikarenakan tidak efisiennya distribusi sumber produksi antara laki - laki dan perempuan di rumah tangga (Laporan Bank Dunia, 2000). Meskipun merujuk data tersebut baik Indonesia dan ASEAN sama - sama belum memuaskan untuk capaian kesetaraan dan keadilan gender. Namun Indonesia yang sebagai negara besar yang dianggap primus interpares di kawasan tentunya sangat diharapkan untuk menjadi suri tauladan di kawasan. Oleh karena itu jika saja Draft RUU KKG yang diajukan hasil Panja 9 Desember 2013 dilanjutkan pembahasannya hingga paripurna; maka kesetaraan dan keadilan gender akan semakin kuat adanya di Indonesia.

\section{Simpulan}

Kajian ini telah melakukan berbagai tilikan secara mendalam terkait dengan urgensi Undang-Undang Kesetaraan dan Keadilan Gender di Indonesia. Menggunakan pendekatan gender dan sistem sosial kajian ini menyajikan analisis terkait ketimpangan dan ketidakadilan gender dalam sistem sosial patriakal di Indonesia. Kemudian dilanjutkan dengan melakukan analisis yang lebih mendalam dengan memotret ketimpangan yang terjadi disandingkan dengan prinsip - prinsip CEDAW yang telah diratifikasi oleh Indonesia sebagai bentuk komitmennya sebagai 
negara-bangsa yang menjadi bagian dari masyarakat dunia. Instrumen - instrumen hukum yang selama ini telah ada ternyata menunjukan masih belum mampu mendorong kondisi kesetaraan dan keadilan gender di Indonesia. Dengan demikian, laki-laki dan perempuan dapat merasakan manfaat, memiliki akses, serta berpartisipasi secara seimbang dan optimal dalam pembangunan. UU tentang KKG diperlukan untuk mempercepat tercapainya persamaan substantif dan kesempatan yang sama antara laki-laki dan perempuan dalam menikmati hak-hak sipil, politik, ekonomi, sosial, dan budaya. Selain itu, UU tentang KKG diperlukan sebagai payung hukum guna mencapai akses dan kondisi yang setara antara laki-laki dan perempuan. Oleh karena itu sangat penting untuk Undang - Undang KKG dilanjutkan pembahasannya sehingga Kesetaraaan dan Keadilan Gender di Indonesia bisa semakin cepat terwujud melalui berbagai strategi pemerintah dalam pemberdayaan perempuan yang semakin kuat dengan adanya Undang - Undang yang menjadi payung hukum.

\section{Endnote :}

${ }^{1}$ Pengakuan pentingnya kesetaraan dan keadilan gender sebagai sebuah kesepakatan tujuan kolektif dunia nampak dengan masuknya agenda tersebut dalam SDGs; Seperti yang telah dinyatakan melalui Sustainable Development Knowledge Platform di bagian Gender Equality and Women Empowerment. Dapat di akses pada alamat https://sustainabledevelopment.un.org/topics/genderequalityandwomensempowerment, terakhir akses 01 November 2016.

${ }^{2}$ Seperti yang diungkap oleh Fahira Idris di dalam artikel sebuah media daring. Dapat diakses di http://www.koran-jakarta.com/mempercepat-pencapaian-kesetaraan-gender/. Terakhir akses 06 November 2016, Pada Pukul 20.00 WIB.

${ }^{3}$ Dikutip dari Naskah Akademis RUU KKG (Kesetaraan dan Keadilan Gender), Tim Kerja PUU-Deputi Perundang-undangan DPR RI, 24 Agustus 2011, hlm. 11

${ }^{4}$ Ibid, hal.9

${ }^{5}$ Ibid.

${ }^{6}$ https://portal.mahkamahkonstitusi.go.id/eLaw/mg58ufsc89hrsg/UUD_1945_Perubahan.pdf. Terakhir akses 06 November 2016, Pada Pukul 20.00 WIB.

7 http://nasional.tempo.co/read/news/2015/03/07/063647808/indonesia-darurat-kekerasanterhadap-perempuan. Terakhir akses 06 November 2016, Pada Pukul 20.00 WIB.

8 https://www.theguardian.com/theguardian/2013/jul/22/bandaranaike-first-woman-primeminister. Terakhir akses 06 November 2016, Pada Pukul 20.00 WIB.

9 Terminologi Glass Ceiling (atap kaca) adalah istilah yang sering digunakan dalam menggambarkan batasan yang tidak terlihat sebagai pembatas terhadap demografi tertentu (Kebanyakan dikaitkan terhadap wanita) untuk dapat berkembang melampaui hierarki di dalam sistem sosial. Lihat. Wiley, John (2012). The Blackwell Encyclopedia of Gender and Sexuality Studies. Vol. 5. John Wiley and Sons.

${ }^{10}$ Meskipun ada pendapat yang menyatakan bahwa 6 (enam) Pasal tersebut yaitu : Pasal 8 , Pasal 15, Pasal 55, Pasal 56, Pasal 58, dan Pasal 59 telah menyebutkan mengenai syarat sekurang-kurangnya $30 \%$ keterwakilan perempuan dalam pemilu, namun dapat terlihat bahwa keterwakilan perempuan $30 \%$ yang dijamin hanya pada tahap penyusunan daftar bakal calon dan tidak ada jaminan dalam daftar calon sementara maupun daftar calon tetap. Oleh karena itu, undang-undang pemilu ini dianggap menyalahi prinsip persamaan 
kesempatan bagi laki-laki dan perempuan untuk dipilih dalam pemilu, karena perempuan harus ada di dalam Daftar Calon Tetap (DCT) untuk dapat dipilih dalam pemilu, dalam Dian Kartikasari, makalah, Semiloka Strategi Pemenangan dalam Pemilu 2014, http:www.koalisiperempuan.or.id, diakses pada tanggal 10 November 2016 jam 22.05 WIB.

${ }^{11}$ http://www.beritasatu.com/politik/210327-kuota-30-keterwakilan-perempuan-di-parlemengagal-tercapai.html. Terakhir akses 06 November 2016, Pada Pukul 20.00 WIB.

12 Menurut penjelasan Triyuni Soemartono (2014) Keberadaan DPD RI hasil amandemen ketiga UUD 1945 pada November 2001, dimaksudkan untuk mengakomodasi aspirasi daerah sekaligus memberi peran yang lebih besar kepada daerah dalam proses pengambilan kebijakan nasional terutama kebijakan yang berkaitan dengan kepentingan daerah.

${ }^{13}$ http://nasional.kompas.com/read/2014/10/27/01430051/8.Kursi.Menteri.Perempu an.di.Kabinet.Kerja.Terbanyak.dalam.Sejarah. Terakhir akses 06 November 2016, Pada Pukul 20.00 WIB.

${ }^{14}$ http://www.dw.com/id/perempuan-finlandia-semakin-percaya-diri/a-2973880.

Terakhir akses 06 November 2016, Pada Pukul 20.00 WIB.

\section{Daftar Pustaka}

\section{Buku dan Jurnal}

Arivia, Gadis. Kebijakan Publik Dalam Pendidikan. Sebuah Kritik Dengan Perspektif Gender. Jurnal Perempuan No.23. 2002. h.83-94

Aryani, Agung, and I. Gusti Ayu. "Mengenal Konsep Gender (Permasalahan dan Implementasinya dalam Pendidikan). 10 halaman." (2002).

Badan Pusat Statistik, 2011. Laporan Studi Kualitatif Partisipasi Perempuan Dalam Politik.

Barlah, Asma, 2007, Cara Quran Membebaskan Perempuan, Yogyakarta.

Bemmelan, Sita Van. Isu Gender di Bidang Pendidikan. Semiloka Pengarusutamaan Gender Bagi Para Perencana di Lingkungan Pendidikan Nasional Kabupaten Badung dan Kota Denpasar. 2002. h.9.

Bemmelen, Sita, and Mies Grijns. "Competing Gender Identities after Reformasi?." Antropologi Indonesia 30.1 (2006).

Correia, Maria C., and Ian Bannon. "Gender and its discontents: Moving to menstreaming development." The other half of gender: Men's issues in development (2006): 245-260.

Clark, Gordon Haddon. The Works of Gordon Haddon Clark (Modern Philosopy, Vol 5). 2008. Hal.28 
Deveaux, Monique. Gender and justice in multicultural liberal states. Oxford University Press, 2007.

De Beauvoir, Simone. The second sex. Random House, 2014.

Echols, John M., and Hassan Shadily. An Indonesian-English Dictionary. Vol. 2. Cornell University Press, 1989.

Faqih, Mansour, 2006, Analisis Gender dan Transformasi Sosial, Pustaka Pelajar, Yogyakarta.

Husain, Djamiah dan Hading, Suraedah. Implementasi Kebijakan Pengarusutamaan Gender Pada Sektor Pendidikan. Jurnal Kajian Perempuan "Bunga Wellu" Volume 14 No. 1, 2009.

Ife, James William. Community development: Creating community alternativesvision, analysis and practice. Longman Australia, 1995.

Islam, Md Saidul, and Md Ismail Hossain. Social Justice in the Globalization of Production: Labor, Gender, and the Environment Nexus. Springer, 2016.

Jalalzai, Farida. Shattered, Cracked, Or Firmly Intact?: Women and the Executive Glass Ceiling Worldwide. Oxford University Press, 2013.

Julia Cleves Mosse, Gender dan pembangunan, penerjemah Hartian Silawati, Yogyakarta: Rifka Annisa Women's Crisis Centre dan pustaka Pelajar, 1993, hlm. 8-9.

Johnson, Elizabeth K. "Grammatical gender and early word recognition in Dutch." Proceedings of the 29th annual Boston University conference on language development. Vol. 1. 2005.

Kania, Dede. " Hak Asasi Perempuan dalam Peraturan Perundang-Undangan di Indonesia. Jurnal Konstitusi, Volume 12 Nomor 4. 2015.

Karl, Marilee. Women and empowerment: Participation and decision making. Vol. 10. London: Zed Books, 1995.

Koentjaraningrat. Kebudayaan, mentalitet, dan pembangunan: bunga rampai. Gramedia, 1974.

Kurniawan, Nalom. "Hak Asasi Perempuan dalam Perspektif Hukum dan Agama." Jurnal Konstitusi 4.1 (2011).

Kusumawardhana, I. (2017a). Dari Internasionalisme Ke Globalisasi: What Next?. Jurnal Populis, 2(3). 
Kusumawardhana, I. (2017b). Understanding The Dynamic of International System Through The Lens of Complex System Approach. Jurnal Hubungan Internasional, 10(1), 90-105.

Kusumawardhana, Indra. "Globalisation And Strategy: Negara, Teritori dan Kedaulatan Di Era Globalisasi." Ilmu Dan Budaya 40, No. 54 (2018).

Lips, Hilary M. Sex \& gender: An introduction . Mayfield Publishing Co, 2001.

Mahon, Joseph. "Existentialism, feminism, and Simone de Beauvoir." (1997).

Mudaris, Hudan. "Diskursus Kesetaraan Gender dalam perspektif Hukum Islam; menuju Relasi Laki-laki dan Perempuan yang Adil dan Setara." Yin Yang 4.2 (2009): 234-248.

Naskah Akademis RUU KKG (Kesetaraan dan Keadilan Gender), Tim Kerja PUUDeputi Perundang-undangan DPR RI, 24 Agustus 2011, hlm. 11

Nurhaeni, Ismi Dwi Astuti. "Penelitian Berperspektif Gender." Makalah Pelatihan Lemlit UNS (2009).

Murniati, A. Nunuk P. "Getar Gender: Perempuan Indonesia dalam Perspektif Agama, Budaya, dan Keluarga." Magelang: Indonesiatera (2004).

Oakley, Anne. "Sex, gender andsociety." London: Temple Smith (1972).

Payne, Malcolm. "Modern social work theory." (2014).

Sahlin, Marshall, 2006, Analsis Dengan Prespektif Gender Atas Majalah Wanita Di Indonesia, Fisipol UGM, Yogyakarta.

Sudarta, Wayan. Konsep Gender Dan Pengarusutamaan Gender. Jurnal Studi Jender SRIKANDI Vol. 3, No. 1 Januari 2004.

Sudarta, Wayan. "Peranan Wanita dalam Pembangunan Berwawasan Gender." Jurnal Studi Jender Srikandi 3.1 (2003).

Sulistiyani, Ambar Teguh. Kemitraan dan model-model pemberdayaan. Gava Media, 2004.

Susiana, Sali. "Urgensi Undang-Undang Tentang Kesetaraan dan Keadilan Gender." Kajian 19.3 (2016): 219-234.

Soemartono, Triyuni. Peran Pemerintah Dalam Pemberdayaan Perempuan. Yayasan Budi Arti, 2014. 
Retno, Wulandari.2010.Budaya Hukum Patriarki v. Feminis. Jurnal Hukum Dosen Tetap pada Fakultas Hukum Universitas Trisakti.

Ritzer, George, and Douglas J. Goodman. "Teori sosiologi modern." (2005). hal 404

Rousseau, Jean-Jacques. The Social Contract: \& Discourses. No. 660. JM Dent \& Sons, 1920.

Rousseau, Jean-Jacques, and Victor Gourevitch. Rousseau:'The Social Contract'and Other Later Political Writings. Cambridge University Press, 1997.

Tim Pusat Studi Wanita Universitas Udayana. Konsep Gender dan Pengarusutamaan Gender. Materi Sosialisasi Gender dan Pengarusutamaan Gender untuk Toga dan Toma di Provinsi Bali. Denpasar. 2003. h. 9.

Udayana, Tim Pusat Studi Wanita Universitas. "Konsep Gender dan Pengarusutamaan Gender." Dempasar: Materi Sosialisasi Gender dan Pengarusutamaan Gender untuk Toga dan Toma di Provinsi Bali (2003).

Al Uyun, Dhia. 2014. Women's Right in Indonesian Constitution, International Journal of Humanities and Social Science, Vol.4, No.8(1); June 2014

Walby, Silvia, 1998, Theorizing Patriarchy Oxford Blackwell, USA.

Wilson, Hall Thomas. Sex and gender: Making cultural sense of civilization. Vol. 24. Brill, 1989.

Wiley, John (2012). The Blackwell Encyclopedia of Gender and Sexuality Studies. Vol. 5. John Wiley and Sons.

Winarno, Budi. Globalisasi: peluang atau ancaman bagi Indonesia. Erlangga, 2008.

Yin, Robert K, Case Study Research: Design and Method, (Sage, 2008)

\section{Sumber Online:}

Koran Jakarta, 2016. http://www.koran-jakarta.com/mempercepat-pencapaiankesetaraan-gender/. Terakhir akses 04 November 2016, Pada Pukul 20.00 WIB.

UN.org, 2016. https://sustainabledevelopment.un.org/about. Terakhir akses 06 November 2016, Pada Pukul 20.00 WIB.

Kemendagri.go.id. http://www.dukcapil.kemendagri.go.id/laporan. Terakhir akses 06 November 2016, Pada Pukul 20.00 WIB. 
http://www.un-documents.net/a37r63.htm. Terakhir akses 06 November 2016, Pada Pukul 20.00 WIB.

Country Gender Profile: Indonesia, Final Report, Japan International Cooperation Agency. 2011. Terakhir akses 06 November 2016, Pada Pukul 20.00 WIB.

http://nasional.tempo.co/read/news/2015/03/07/063647808/indonesia-daruratkekerasan-terhadap-perempuan. Terakhir akses 06 November 2016, Pada Pukul 20.00 WIB.

https://www.theguardian.com/theguardian/2013/jul/22/bandaranaike-first-womanprime-minister. Terakhir akses 06 November 2016, Pada Pukul 20.00 WIB.

http://hdr.undp.org/en/composite/GDI. Terakhir akses 06 November 2016, Pada Pukul 20.00 WIB.

http://www.bbc.com/news/uk-politics-36788782. Terakhir akses 06 November 2016, Pada Pukul 20.00 WIB.

http://www.bbc.com/news/uk-politics-36788782. Terakhir akses 06 November 2016, Pada Pukul 20.00 WIB.

http://www.nationalreview.com/article/442063/hillary-clinton-lost-2016presidential-election-sexism-glass-ceiling. Terakhir akses 06 November 2016, Pada Pukul 20.00 WIB.

Profil Anggota DPR dan DPD RI 2014-1019, Pusat Kajian Politik Universitas Indonesia. 2014. http://www.puskapol.ui.ac.id/wpcontent/uploads/2014/12/. Terakhir akses 06 November 2016, Pada Pukul 20.00 WIB.

http://www.beritasatu.com/politik/210327-kuota-30-keterwakilan-perempuan-diparlemen-gagal-tercapai.html. Terakhir akses 06 November 2016, Pada Pukul 20.00 WIB.

http://nasional.kompas.com/read/2014/10/27/01430051/8.Kursi.Menteri.Perempuan. di.Kabinet.Kerja.Terbanyak.dalam.Sejarah. Terakhir akses 06 November 2016, Pada Pukul 20.00 WIB.

https://m.tempo.co/read/news/2014/10/26/078617142/ini-dia-menteri-luar-negeriwanita-pertama-ri. Terakhir akses 06 November 2016, Pada Pukul 20.00 WIB

http://www.dw.com/id/perempuan-finlandia-semakin-percaya-diri/a-2973880. Terakhir akses 06 November 2016, Pada Pukul 20.00 WIB. 
https://www.bps.go.id/website/pdf_publikasi/watermark\%20_Laporan\%20Studi\%20 Kualitatif\%20Partisipasi\%20Perempuan\%20dalam\%20Politik.pdf. Terakhir akses 06 November 2016, Pada Pukul 20.00 WIB.

https://www.bps.go.id/linkTabelStatis/view/id/983. Terakhir akses 06 November 2016, Pada Pukul 20.00 WIB.

http://www.focus-economics.com/countries/indonesia. Terakhir akses 06 November 2016, Pada Pukul 20.00 WIB.

http://digilib.uinsuka.ac.id/11372/1/BAB\%20I,\%20V,\%20DAFTAR\%20PUSTAKA .pdf. Terakhir akses 06 November 2016, Pada Pukul 20.00 WIB. 